\title{
Performance of Supply Chain of Arabica Coffee in Kerinci Regency Jambi Province Indonesia
}

\author{
Ira Wahyuni ${ }^{1, *}$ Ardhiyan Saputra ${ }^{2}$, Endy Effran ${ }^{3}$ \\ ${ }^{123}$ Department of Agribusiness, Faculty of Agriculture, Universitas Jambi \\ "Corresponding author. Email: irawahyuni@unja.ac.id
}

\begin{abstract}
This study aims to analyze the performance of the Arabica coffee supply chain in Kerinci Regency. The selection of the research location was carried out deliberately, on the grounds that the research area was a center for Arabica coffee. The determination of farmer respondents was carried out using simple random sampling method. Determination of other supply chain actors using the Snowball Sampling method. Methods of data analysis using descriptive and quantitative analysis. The results of the study showed that there are two models of arabica coffee supply chains, first, specialty coffee supply chains and second, conventional coffee supply chains. The supply chain product flow moves from upstream to downstream, starting from: main suppliers of Arabica Coffee Farmers- Collectors- Product Processing Business Groups (UPH)- Koperasi Alam Kerinci (ALKO)- Wholesalers- Exporters- Retailers- Hortel- Restaurants- Coffee ShopsConsumers. Financial flow moves in two directions from downstream to upstream, and information flows in two directions reciprocally, namely from upstream to downstream and from downstream to upstream regarding price, quantity, quality, market, funds and risk. Arabica coffee supply chain performance has not been efficient in terms of the value of the marketing margin and farmer's share.
\end{abstract}

Keywords: Supply Chain, Business Actors, Performance and Arabica Coffee.

\section{INTRODUCTION}

Indonesia is the fourth largest coffee bean producing country with an average production of around 639 thousand tons per year or around $8 \%$ of world coffee production. The first largest producing country is Brazil with a production of 3.08 million tons per year, the second is Vietnam with 1.77 million tons per year and the third is Colombia with a production of 840 thousand tons per year (ICO, 2019). The composition of coffee production in Indonesia is $72.84 \%$ robusta coffee and $27.15 \%$ arabica coffee (BPS, 2019). Coffee consumption in Indonesia has increased, in 2017 as much as $0.8 \mathrm{~kg}$ per capita per year and in 2018 to $1.3 \mathrm{~kg}$ per capita per year and it is predicted that in 2019-2020 it will be $1.39 \mathrm{~kg}$ per capita per year (BPS, 2018). The growth of Indonesian coffee consumption from 2016 to 2021 is $8.22 \%$ per year. In 2021, coffee supply is predicted to reach 795 thousand tons with consumption of 370 thousand tons, resulting in a surplus of 425 thousand tons [1].

Coffee production from each country is greatly influenced by the productivity of the coffee plant. The average productivity of Indonesian coffee of $563 \mathrm{~kg}$ per hectare is still very small compared to Brazil's $1421 \mathrm{~kg}$ per hectare and Vietnam's $2499 \mathrm{~kg}$ per hectare and Colombia's $846 \mathrm{~kg}$ per hectare. Therefore, Indonesia's coffee productivity needs to be improved because Indonesia still has the potential to increase coffee productivity when viewed from the coffee productivity of other countries. Increasing the productivity of coffee plants is closely related to improvements in coffee cultivation. If the productivity of Indonesia's coffee plants can be increased so that in the end it can increase Indonesian coffee production and increase Indonesia's total exports. Based on BPS data (2017), coffee contributed US \$ 1037.2 million or $33.67 \%$ of the total total export of Indonesian plantation commodities. Therefore, it can be said that coffee is Indonesia's leading export commodity and has an important role in the Indonesian economy.

Indonesian coffee, occupying an important position, supplies coffee to the Domestic Market and the Export Market. Arabica coffee that is widely demanded by the export market is specialty coffee or what is called premium coffee, which maintains the taste of each according to the SOP. Each region has a unique coffee 
taste, which is called geographic indication coffee, while still maintaining the inherent taste of the coffee.

Coffee is a commodity from the plantation sector which has a high role for the economy. Remind that coffee is a trade commodity between countries which is very important as state income [2]. Coffee plantations also have the ability to encourage upstream and downstream industries. Based on data from BPS Indonesia, there are 13 provinces as the largest coffee producer, one of which is Jambi Province, where the coffee center in Jambi Province is located in Kerinci Regency. The latest data shows that the area of coffee plants in Kerinci Regency is 809 hectares with a production of 171 tons and a productivity of $638 \mathrm{~kg}$ per hectare with a total of 1440 coffee farmers [3].

One of the coffee commodity problems is related to the supply chain. The supply chain is the flow (distribution) of raw materials and products obtained by consumers. The risk in marketing products from the harvest is a risk that is often faced by farmers. The supply chain is formed from the inability of business actors to produce products from raw materials to products that are ready for consumer consumption. The supply chain is formed from the joining of business actors in distributing their products to the final consumer. Supply chain actors have different roles and need each other in producing quality goods that can be accepted by coffee consumers, especially Arabica coffee. Based on the existing phenomenon, researchers are interested in researching with the aim of describing the flow of Arabica coffee processing based on supply chain actors and analyzing the performance of the Arabica coffee supply chain in Kerinci Regency.

\section{RESEARCH METHODS}

The location of this research is in Kerinci Regency. The selection of the research area was carried out purposively by considering the location of the study, namely the Arabica coffee production center in Jambi Province, which was in accordance with the analyzed topic. The farmers who will be sampled are Arabica coffee farmers and this activity will be carried out in April-October, 2020.

Field data is an important source of information in this activity. Field information is collected by asking questions to respondents with a structured list of questions. Respondents are supply chain actors ranging from upstream (Arabica coffee farmers) to upstream (intermediary traders). The data needed from supply chain actors are the Arabica coffee transaction system, horizontal and vertical information and the marketing channels for Arabica coffee. Other sources of data needed are supporting information obtained from the Regional Government of Kerinci Regency and literature studies, the Central Bureau of Statistics
(BPS), the Kerinci Regency Plantation Service, BPP Kayu Aro District and research reports, information and literature related to this activity.

The method of determining the respondent is done by simple random sampling and snowball sampling. Simple Random Sampling method to determine the respondents of Arabica coffee farming was done randomly. The research sample is a portion of the population taken as a data source and can represent the entire population. The research sample was taken $10 \%$ (125 households) from the total population $(1,249$ households). Snowball sampling was used for the sample of Arabica coffee chain suppliers. The three districts were selected with the most number of farmers and also the most extensive farming and the highest production of Arabica coffee. The selected districts were Kayu Aro District, Gunung Tujuh District and Kayu Aro Barat District. The snowball sampling method is used to determine the received supplies from Arabica coffee farmers to the final consumers. Data and information obtained from first stage supply chain actors and up to the last stage supply chain actors. To determine the description of the Arabica coffee supply chain in Kerinci Regency, it was carried out by conducting descriptive analysis and to analyze the work of the Arabica coffee supply chain.

\section{RESEARCH RESULTS AND DISCUSSION}

\subsection{Description of Arabica Coffee Processing Flow based on Supply Chain}

Arabica coffee processing includes two channels, first the specialty coffee processing line and the second conventional processing flow. Starting from the process of picking fresh red coffee beans to postharvest, Hard Skin (HS) processing, green bean processing, coffee powder making and shipping to buyers. Farmers harvest red coffee beans and then distribute them to the Product Processing Unit (UPH) for further processing. The beans that have been picked are processed directly not more than 12 hours after harvesting until the fermentation process so that the coffee cherries are not attacked by fungi.

The processing and distribution of cooperative member farmers is carried out by small scale farmers in their respective UPH. Meanwhile, farmers who are not members of large-scale cooperatives) are carried out at home and distributed to consumers. Small-scale noncooperative farmers distribute their harvest through intermediate traders. Arabica coffee processing flow can be seen in Figure1. 


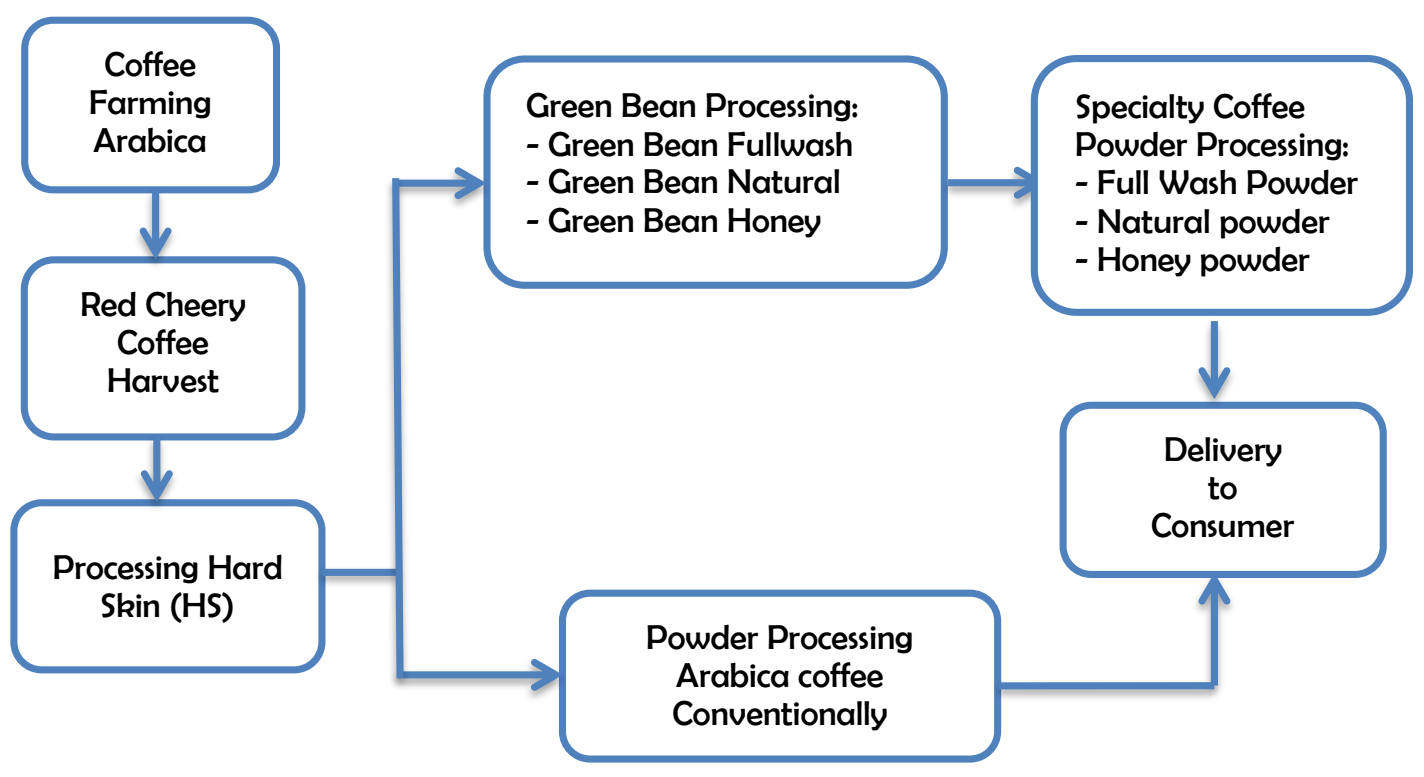

Figure 1. Arabica Coffee Processing Flow in Kerinci Regency

Arabica coffee processing consists of processing full-wash coffee beans, semi-wash coffee beans processing, natural dry processing and honey processing. Coffee processing in Kerinci District differs between farmer members of the cooperative and farmers who are not members of the cooperative. The full wash harvesting process produces cleaner, lighter, softer coffee and a sharp acidity, while the semi-wash produces coffee with a sharper sweet taste, lower acidity, and a more distinctive taste. Large-scale noncooperative farmers have a different coffee processing process from small-scale non-cooperative farmers. Large-scale non-cooperative farmers use honey processes, while small-scale non-cooperative farmers do not process coffee because it is distributed directly to collectors. However, some small-scale noncooperative farmers use a full wash process with a wet milling process using simple equipment to reduce the risk of failure in the coffee processing process. There are 3 grades of specialty Arabica coffee. The quality class that is mostly produced and accepted by the market is specialty coffee grade 1 .

\subsection{Analysys of Supply Chain of Arabica Coffee in Kerinci Regency}

\subsubsection{Product Flow}

The flow of Arabica coffee products consists of two patterns, namely the flow of specialty Arabica coffee products or premium coffee and conventional Arabica coffee products. Specialty coffee is the manufacture of coffee in accordance with the agreed Standard Operating Procedure (SOP) for kerinci arabica coffee, so that the taste of each specialty coffee production does not change. The product that is flowed in this supply chain is arabica coffee beans. The product flow started from Arabica coffee farmers, farmers growing Arabica coffee to produce red cheery coffee cherries. Farmers sell their crops after the Arabica coffee cherries are sacked from the land. Then the farmer contacts the trader when the farmer is ready to harvest the Arabica coffee fruit. The transaction begins by weighing the harvest from the farmers first, then the Arabica coffee fruit weighing continues to be paid in cash by the trader. After being weighed, the Arabica coffee cherries are then transported by car to the warehouse.

Collector traders pack arabica coffee cherries into sacks containing $50 \mathrm{~kg}$ which will then be taken to the wholesaler for processing the red cheery Arabica coffee fruit into coffee beans and distributed to the buyer. Every season, the collector traders have a collection capacity of 30 tons depending on the amount of capital they have. Collecting traders bear transportation costs of Rp. 100,000 per one delivery to the warehouse and to the wholesaler.

The big traders then carry out the process of packaging coffee to be put into sacks in order to facilitate the delivery process to big cities. One form of product in this supply chain product flow, namely coffee cherries that are flowed from farmers to collector traders, then flowed to wholesalers or ALKO cooperatives, then flowed back into the hands of end consumers. The flow of Arabica coffee products from farmers to consumers has not been well integrated because there are uncertain cycles so that the time of shipment or the quota sent cannot be predicted properly. For details, it can be seen in Figure 2. 


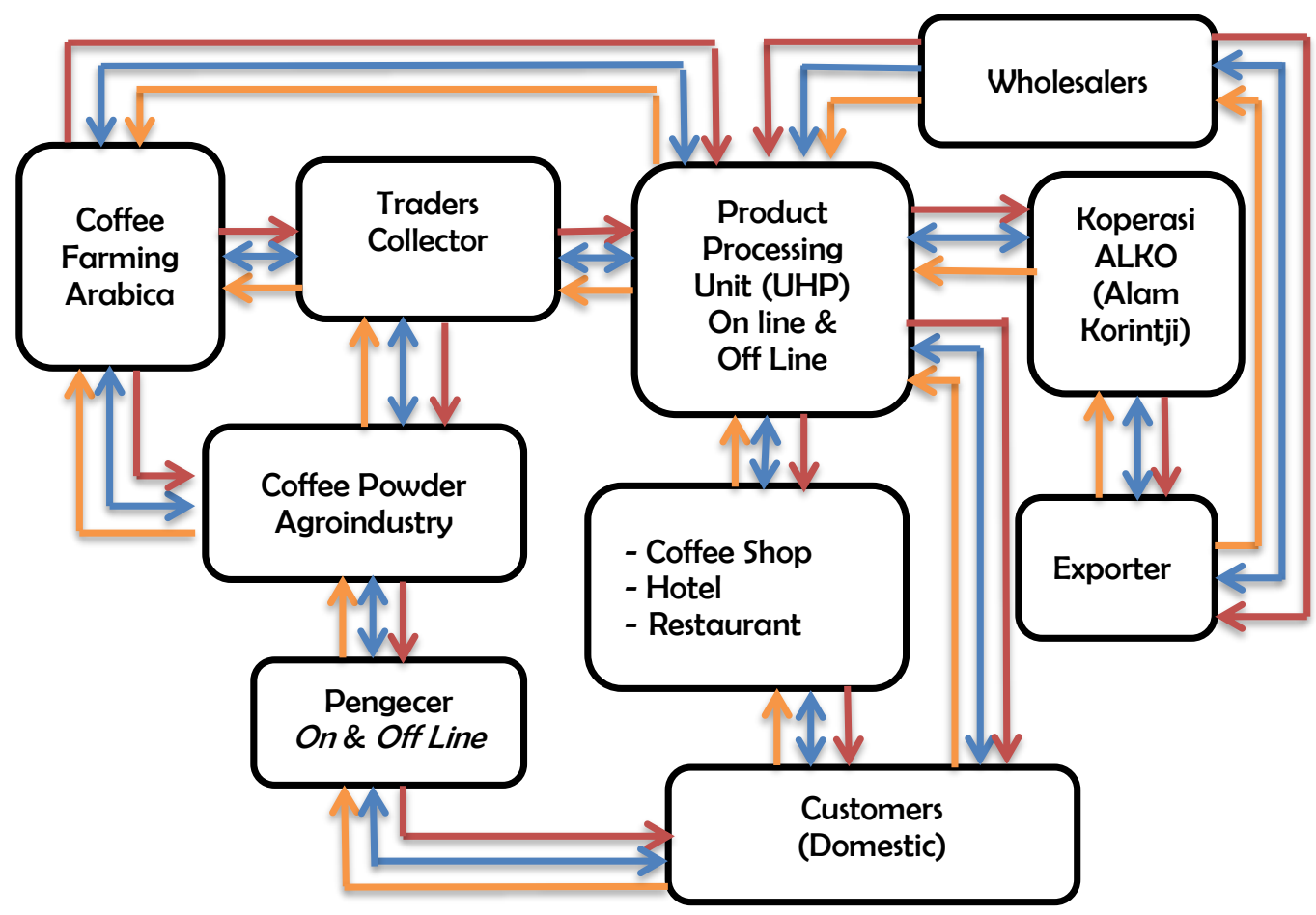

Product Flow Financial Flow Information Flow:

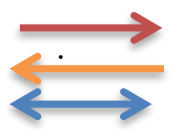

Figure 2. Analysis of Supply Chain of Arabica Coffee

Arabica coffee supply chains are determined by partners. Partners are external actors who are influential and play an important role in business functions so that performance becomes more efficient. Work partners have an important role in providing training and direct mentoring to coffee farmers, and guiding young farmers in dealing with problems that often occur. Based on this, partners in the supply chain make the value chain as a supply chain actor more prosperous and get more benefits compared to other supply chain actors.

Inclusive business is a policy to be able to increase socio-economic development by involving smallholders in business partners along the supply chain to achieve competitiveness. Partners in the supply chain for cooperative member farmers, namely the Regional Government (PEMDA) of Kerinci Regency, the Association of Indonesian Coffee Farmers (APEKI) and Bank Indonesia (BI). These partners provide training, tool assistance, direct guidance and consultation. The local government provides assistance in order to increase resources, such as providing counseling, training, specialty coffee intensification activities, counseling on the development of coffee quality, and making policies. APEKI acts as the farmer's representative. The Regency Coffee Training Center functions to provide training, counseling and assistance for superior seeds. Bank Indonesia (BI) acts as a provider of capital and loans for farmers.

The Koperasi Alam Korintji (ALKO) harvests and processes mostly coffee, namely high quality Arabica coffee, through environmentally sustainable farming management practices with local farmers around the foot of Mount Kerinci (3805 masl). The ALKO cooperative offers coffee shop businessmen and coffee lovers an in-depth experience of the coffee process they enjoy, by being invited to a coffee garden tour. Coffee lovers will be invited to tour the coffee plantation around the slopes of the foot of Mount Kerinci with an altitude of $1,300 \mathrm{~m}-1650 \mathrm{~m}$ above sea level, to experience firsthand the authenticity of coffee cultivation, in order to inspire coffee lovers, increase knowledge of the coffee industry and can even change the paradigm of coffee connoisseurs towards coffee itself.

ALKO's cooperative products are green bean with full wash process, honey process and natural process. The production process is at one point of production with great care and accuracy in sorting so that quality is maintained. For Natural process coffee, after the coffee is sorted, then dried in the sun to dry in a container before peeling the skin, for about 35 days depending on weather conditions. As for the full wash process, after the coffee is peeled off the outer skin then 
the coffee is dried in the sun for 2 days, then the outer skin of the coffee (HS) is removed and then dried in the form of beans until the coffee becomes dry, for about 5 days for get green beans and a quality full wash process.

\subsubsection{Financial Flow}

Financial flows in the Arabica coffee supply chain in Kerinci Regency are cash and non-cash flows of funds, in the form of payments for Arabica coffee products sold to suppliers. This flow of funds has the opposite direction of product flow, if the flow of products is from upstream to downstream, the flow of funds from downstream to upstream which can be seen in Figure 2. In the supply chain, the payment money is obtained for products sold to partners. The payment money is used by supply chain actors as capital to resume production, thus forming a separate cycle.

The financial flow starts from the final consumer to the main supplier, namely coffee farmers. Consumers pay directly after buying the coffee product with money to middlemen and farmers. The flow of funds is usually used again for farming capital and capital to purchase products. The flow of funds for Arabica coffee also comes from partners. Partner funds come from the Jambi branch of Bank Indonesia which helps with funding. So that a chain is formed in the form of a cycle.

Financial flow is the flow of money or funds flowing from each supply chain actor to the supply chain which is directly linked to the previous supply chain actor. Collector traders, wholesalers and cooperatives pay the Arabica coffee harvest to farmers directly and in cash after the traders finish transporting the coffee. Meanwhile, large traders to collector traders occur in cash or non-cash via bank transfers. Traders can bring Arabica coffee if they have paid an amount according to the price of Arabica coffee they buy. Meanwhile, the financial flow from final consumers to coffee processing wholesalers and cooperatives is done via transfer.

The management of the financial flow of the Arabica coffee supply chain in Kayu Aro District has been well managed, but the weaknesses are that there is no written contract regarding the quantity and quality or the form of coffee processed products and the price of coffee purchased where the contract agreement is only based on trust and proximity to the perpetrator. other supply chains.

\subsubsection{Information Flow}

Arabica coffee supply chain information flow in Kerinci Regency, occurs in two reciprocal directions, starting from downstream to upstream and from upstream to downstream. Information can be in the form of price, quantity and form of processed Arabica coffee. Prices depend on the product supplied, whether in the form of red cheery coffee, green beans. Cooperatives and Local Governments, agencies related to assisting farmers how to cultivate with GAP and SOP, developing coffee businesses and assisting coffee shop businesses, developing coffee commodities, there is a Coffee Cultivation division, overseeing the ALKO ICS (Internal Control System) team to maintain the quality of coffee starting the process nursery, planting, care and harvest as well as post-harvest. ALKO's CoFounder who handles the production division in the ICP (Internal Control Production) team, post-harvest, supervises production from farm to target market. There are also those who inform in the field of finance and investment who provide information about investment capital and funding as well as funding assistance from the government and funding assistance from abroad. Information flow can be seen in Figure 2. Information about coffee marketing and informing market links and other information can be asked in the field of public relations at link market and public relations at the ALKO Cooperative. With the support of the government as well as the Jambi Province Bank Indonesia Representative Office, Arabica Coffee is managed through the Koperasi Koerintji Barokah in Jernih Jaya Village, Gunung Tujuh District.

Information flow is an important component in the smooth flow of both product and financial flows in the Arabica coffee supply chain. This information is useful for maintaining a sense of trust between each member of the Arabica coffee supply chain. Transparency of information must always be maintained in order to avoid conflict and facilitate business operations in the long term. The information provided can be in the form of production information, market conditions, prices and others related to the Arabica coffee supply chain.

The information provided by farmers to collecting traders is related to information regarding the productivity of Arabica coffee fields. Farmers also convey price information to fellow farmers as a reference in the sales process to collector traders in the bargaining process. On the other hand, Arabica coffee farmers also receive information from collectors in the form of price information and market developments based on the quality and quantity of Arabica coffee cherries the market wants.

Information that is passed by collectors to wholesalers of processing products includes product availability, types of coffee products, and quantity of arabica coffee products. On the other hand, the information provided by wholesalers to collecting traders is information related to the demand for Arabica coffee, the quality and quantity of the product from the final consumer. Wholesalers also receive information from out-of-town wholesalers regarding demand for Arabica coffee, market conditions, prices and product quality from end consumers and vice versa. Information regarding quality and quantity as well as demand is obtained from traders who are directly 
related to the final consumer. All complaints and input from the final consumer are accommodated by the traders and then submitted to all Arabica coffee supply chain actors.

\subsection{Performance of Supply Chain of Arabica Coffee}

Arabica coffee supply chain performance can be assessed from the business processes of supply chain actors which can be assessed from marketing efficiency with the tools used, namely marketing margin analysis, farmer share analysis and profit to cost ratio analysis of arabica coffee.

\subsubsection{Arabica Coffee Marketing Margin Analysis}

Margin analysis is the difference in price received by each supply chain actor by each member of the supply chain in bringing the product into the hands of consumers and to determine the difference in the price of Arabica coffee products received by consumers and coffee producers. The Arabica coffee supply chain pattern in Kerinci Regency is as follows:

Pattern I: Coffee Farmers- Collector Traders- Product Processing Unit (UHP) - ALKO (Alam Korintji) Cooperative - Exporters.
Plattern II: Coffee Farmers-UHP-WholesalersExporters.

Pattern III: Coffee Farmers-Collector Traders-UHPConsumers

Pattern IV: Coffee Farmers - Collector Traders - UHP

- Coffee Shops, Restaurants, Hotel - Consumer

Pattern V : Coffee Farmers - Collecting Traders Powder Processing Agroindustry Coffee-Retailers Consumers

Pattern VI: Coffee Farmers - Coffee Powder Processing Agroindustry - Retailers - Consumer

The efficient marketing margin is in pattern I, followed by pattern 2 and the smallest is in pattern $\mathrm{V}$. It is said to be efficient because the average value of the cost margin of arabica coffee $\left(\mathrm{sk}_{\mathrm{i}}\right)$ is greater than the average profit margin of arabica coffee $\left(s b_{i}\right)$.

\subsubsection{Farmer's Share}

Farmer's share is a percentage of the selling price of Arabica coffee farmers received by farmers against the selling price of Arabica coffee received by consumers. The greater farmer's share value reflects the more efficient supply chain.

Table 1. Analysis of Farmer's Share of Arabica Coffee in Kerinci Jambi Regency, Jambi Province, 2020

\begin{tabular}{cccc}
\hline $\begin{array}{c}\text { Pattern } \\
\begin{array}{c}\text { Aupply Chain } \\
\text { Arabica Coffee }\end{array}\end{array}$ & $\begin{array}{c}\text { Arabica Coffee Prices } \\
\text { at The Farmer Level } \\
(\mathrm{Rp} / \mathrm{Kg})\end{array}$ & $\begin{array}{c}\text { Arabica Coffee Prices } \\
\text { at The Consumer Level } \\
(\mathrm{Rp} / \mathrm{Kg})\end{array}$ & $\begin{array}{c}\text { Farmer's } \\
\text { Share }(\%)\end{array}$ \\
\hline I & $11.000,00$ & $180.000,00$ & 6,11 \\
II & $12.000,00$ & $160.000,00$ & 7,50 \\
III & $10.000,00$ & $120.000,00$ & 8,33 \\
IV & $10.000,00$ & $80.000,00$ & 12,50 \\
V & $8.500,00$ & $65.000,00$ & 13,08 \\
VI & $9.500,00$ & $60.000,00$ & 15,83 \\
\hline
\end{tabular}

In Table 1, it can be seen that the highest farmer's share value $(15.83 \%)$ is seen in pattern VI and the lowest value is in pattern I $(6.11 \%)$. The farmer's figure from Table 1 for all percentage patterns is relatively low, this is because the price of coffee at the farmer level (red cheery coffee) is almost the same for all patterns, while the price of green been (raw coffee beans that have been peeled and processed green bean (fullwash bean, natural green bean and green bean honey) and processed coffee with a variety of processing processes for making specialty coffee powder (full wash coffee powder, natural coffee powder and honey coffee powder) at the consumer level are very different per $\mathrm{kg}$. typical of the selling price of red cheery coffee beans and the selling price of premium ground coffee or specialty coffee and conventionally processed coffee powder In pattern VI, although the price of red cheery bean coffee $(\mathrm{Rp} 9,500.00 / \mathrm{kg})$ is relatively low but due to the powder price coffee (Rp. $60,000.00 / \mathrm{kg}$ ) with conventional processing is also relatively low.

\subsubsection{Analysis of the Benefits of Marketing Costs of Arabica Coffee}

The ratio of profit to marketing cost of Arabica coffee in Kerinci Regency is relatively evenly distributed in 6 supply chain patterns. The highest ratio is in pattern II, which is 69.19 , which means that every 1 (one) rupiah of marketing costs incurred in pattern I can provide a profit of Rp. $69.19 / \mathrm{kg}$. For details, see Table 2. 
Table 2. Analysis of Profit Ratio and Marketing Cost of Arabica Coffee in Kerinci Jambi Regency Jambi Province, 2020

\begin{tabular}{cccc}
\hline $\begin{array}{c}\text { Pattern } \\
\text { Arpply Chain } \\
\text { Arabica Coffee }\end{array}$ & $\begin{array}{c}\text { Marketing Profit } \\
\text { Arabica Coffee } \\
(\mathrm{Rp} / \mathrm{kg})\end{array}$ & $\begin{array}{c}\text { Marketing Costs } \\
\text { Arabica Coffee } \\
(\mathrm{Rp} / \mathrm{kg})\end{array}$ & $\begin{array}{c}\text { Ratio of Profit to } \\
\text { Marketing Cost of Arabica } \\
\text { Coffee }\end{array}$ \\
\hline I & $125.050,30$ & $1.850,55$ & 67,57 \\
II & $110.770,00$ & $1.600,00$ & 69,19 \\
III & $82.650,00$ & $1,445,60$ & 57,17 \\
IV & $53.000,50$ & $1.505,50$ & 35,20 \\
V & $45.800,50$ & $1.345,00$ & 34,05 \\
VI & $46.584,50$ & $1.260,50$ & 36,96 \\
\hline
\end{tabular}

In Table 2, pattern $\mathrm{V}$ shows the lowest ratio of profit to marketing cost of Arabica coffee (34.05). Even though the value in Pattern $\mathrm{V}$ is the lowest, the profit level is still high. Suppliers have obtained a high level of profit, but Arabica coffee farmers in every sale of red cheery coffee beans are the same, namely getting a relatively low price per $\mathrm{kg}$ of coffee beans (IDR 8,500IDR 11,000 / kg). Even at the beginning of the Covid 19 epidemic, the price of red cheery coffee beans was only Rp.4,000, - Rp.7,000, -/kg) Kerinci Arabica coffee business is very profitable. Especially for coffee traders. For supply chain actors, a large amount of capital is needed for supply purposes and also for postharvest processing activities until coffee products are packaged according to the variety of products produced. From harvest time until the product is ready to market, it takes 2 months.

\section{CONCLUSIONS}

1. The supply chain for Arabica coffee in the study area is determined by partners. Supply chain actors already have clear targets and markets, namely serving supplies to the domestic market and the export market. The flow of funds is carried out in cash and non-cash as well as the existence of a partner financing institution (Bank Indonesia Jambi Branch). Information on the price and quality and quantity of Arabica coffee is transparent enough between supply chain actors.

2. The performance of suppliers in the research area is very good, according to Good Agriculture Practices (GAP) of coffee and in accordance with Standard Operating Procedures (SOP), both in producing coffee beans (farming) and processed coffee products. From the aspect of distribution, Arabica coffee products are efficient but not yet optimal. Likewise, the flow of funds and information has not been maximal.

Source of Funding :

This research was conducted based on the letter of assignment of application research fund recipients received from Jambi University through the Institute for Research and Community Service, Universitas Jambi.
Conflict of Interest :

The author states there is no conflict of interest in the implementation of this research

\section{REFERENCES}

[1] Direktorat Jendral perkebunan, 2018. Performance Report of the Directorate General T.A 2018 Coffee Plantation. Ministry of Agriculture.

[2] Badan Pusat Statistik. 2018. Indonesia in Figures 2019. BPS Indonesia.

[3] Dinas Perkebunan Provinsi Jambi. 2018. Plantation Statistics of Jambi Province. 